\title{
Prevalence and quantitative analysis of Epstein-Barr virus DNA and Porphyromonas gingivalis associated with Japanese chronic periodontitis patients
}

\author{
Ayako Kato • Kenichi Imai • Kuniyasu Ochiai • \\ Yorimasa Ogata
}

Received: 9 September 2014 / Accepted: 8 December 2014 /Published online: 18 December 2014

(C) The Author(s) 2014. This article is published with open access at Springerlink.com

\begin{abstract}
Objective A number of studies have recently suggested Epstein-Barr virus (EBV) involvement in the pathogenesis of periodontitis. In this study, we investigated the association between major periodontopathic bacteria Porphyromonas gingivalis (P. gingivalis) and EBV in Japanese chronic periodontitis (CP) patients.

Materials and methods A group of 25 patients with CP participated in the study along with 13 individuals without periodontitis. Subgingival samples were obtained with paper points. Quantitative real-time polymerase chain reaction (PCR) was used to detect EBV DNA and $P$. gingivalis.

Results In the CP patients, EBV DNA and $P$. gingivalis were detected in both $80 \%$ of sites with probing pocket depths (PPD) of $\geq 5 \mathrm{~mm}$ and in 40 and $36 \%$ of sites with PPD $\leq 3 \mathrm{~mm}$, respectively. EBV DNA and $P$. gingivalis were detected in 50 and $27 \%$ of the sites in periodontally healthy individuals. Coexistence of EBV DNA and $P$. gingivalis was significantly higher in the deeper PPD sites of CP patients $(68 \%)$ than in the PPD sites of the healthy controls $(15 \%)$ and shallow PPD sites of CP patients (12\%). PCR-positive deeper PPD sites of $\mathrm{CP}$ patients for EBV DNA and $P$. gingivalis range between $3.74 \times 10^{3} \sim 2.83 \times 10^{9}$ and $2.73 \times 10^{5} \sim 6.65 \times 10^{9}$ (copies/ml), respectively.
\end{abstract}

\footnotetext{
A. Kato

Department of Periodontology, Nihon University School of Dentistry at Matsudo, Chiba 271-8587, Japan

K. Imai $\cdot$ K. Ochiai

Department of Microbiology, Division of Immunology and Pathobiology, Dental Research Center, Nihon University School of Dentistry, Tokyo 102-8310, Japan

Y. Ogata $(\bowtie)$

Department of Periodontology and Research Institute of Oral

Science, Nihon University School of Dentistry at Matsudo,

Chiba 271-8587, Japan

e-mail: ogata.yorimasa@nihon-u.ac.jp
}

Conclusion These results suggest an association between EBV DNA, P. gingivalis, and CP in Japanese individuals. Further studies are required to clarify this association; however, we believe that our enhanced understanding of the pathogenesis of periodontal diseases involving viral infections will lead to new treatments.

Keywords Chronic periodontitis · Epstein-Barr virus · Periodontopathic bacteria

\section{Introduction}

The pathogenesis of periodontitis is a multiple-step process involving complex interactions between specific bacterial factors, host factors, and a variety of environmental factors. Periodontitis is caused by specific periodontopathic bacteria, and it is evident that the immune responses against bacterial products and the subsequent production of proinflammatory cytokines are important for tissue destruction of the periodontium [1]. Bacterial plaque is considered to be the principal etiological factor in the onset and progression of periodontitis [2]. Porphyromonas gingivalis (P. gingivalis), Tannerella forsythia, and Treponema denticola are related to clinical parameters of chronic periodontitis, such as probing pocket depth (PPD) and bleeding on probing (BOP), and Aggregatibacter actinomycetemcomitans is associated with aggressive periodontitis characterized by rapid alveolar bone loss $[3,4]$. In microbiological diagnosis of periodontal diseases, the subgingival plaque is commonly used to detect and quantify the bacterial species [5, 6]. Interestingly, herpes virus has been suggested to be involved in the etiology of periodontal diseases because bacterial activity does not adequately explain the clinical characteristics of periodontal diseases [7].

Epstein-Barr virus (EBV) is an enveloped herpes virus with double-stranded DNA that only infects humans. In 
addition, EBV is a ubiquitous virus that infects most individuals by early adulthood [8]. In primary human infection, cellfree EBV in saliva infects naive B lymphocytes, causing them to become proliferating blasts [9]. It then establishes a latent infection in those lymphocytes, which are largely nonpermissive for virus replication [10]. Among immunocompromised hosts, EBV is frequently reactivated and can induce infectious mononucleosis, autoimmune diseases, several malignancies such as Burkitt's lymphoma, Hodgkin's disease, nasopharyngeal carcinoma, and post-transplant lymphoproliferative disorders [8-13].

Recently, a positive association has been reported between periodontitis and EBV infection [14-16]. EBV DNA is frequently detected in saliva, salivary glands, gingival crevicular fluid, and gingival tissues [15, 17-23]. Higher levels of EBV DNA have been detected in the saliva of patients with chronic periodontitis or aggressive periodontitis [16, 17, 24]. Moreover, we demonstrated a relationship between microbial interactions and the etiology of periodontal diseases and discovered that $P$. gingivalis can induce EBV reactivation through epigenetic regulation [25].

EBV replicates at salivary glands, oral mucosal membrane, and nasopharyngeal epithelials $[26,27]$. EBV DNA was detected in the throat washings of $90 \%$ of healthy adults and in the saliva of $38 \%$ of healthy children in Japan [27]. However, no studies have evaluated the prevalence and quantitative of EBV DNA in chronic periodontitis among the Japanese. Therefore, the purpose of this study was to determine the prevalence and quantitative analysis of EBV DNA and $P$. gingivalis among Japanese patients with chronic periodontitis.

\section{Material and methods}

\section{Sampling}

Thirteen periodontally healthy individuals (mean \pm SD age $52.9 \pm 18.0$ ) and 25 chronic periodontitis (CP) patients (mean \pm SD age $54.2 \pm 13.8$ ) were included in this study. They received dental care at Nihon University Hospital School of Dentistry at Matsudo, Japan. The Institutional Internal Review and Ethics Board at the Nihon University School of Dentistry at Matsudo approved the study (EC14-11-027-1). Written informed consent was obtained from each study subject after all procedures had been fully explained. CP patients were defined as the presence of at least two sites with probing pocket depth (PPD) $\geq 5 \mathrm{~mm}$ and attachment loss of more than $5 \mathrm{~mm}$. A group of 13 individuals without periodontitis were included as healthy controls (HC). Subjects showed no clinical signs of gingival inflammation and attachment loss; moreover, no detectable bone loss was confirmed through radiographic examination and PPD $\leq 3 \mathrm{~mm}$. All subjects were systemically healthy and had no history of periodontal treatment or any type of antibiotic therapy for at least 3 months prior to the present study. A total of 50 subgingival plaque samples were collected from two periodontal sites of PPD $(\geq 5$ and $\leq 3 \mathrm{~mm}$ ) among $25 \mathrm{CP}$ patients, and 26 subgingival plaque samples were collected from two sites of PPD $(\leq 3 \mathrm{~mm})$ among 13 periodontally healthy individuals. Before sampling, supragingival plaque was removed with sterile cotton pellets. Sterile paper points were then inserted to the sample site and retained for $30 \mathrm{~s}$ (three times). The paper points were pooled in microcentrifuge tubes and stored at $-80{ }^{\circ} \mathrm{C}$ until DNA extraction.

DNA extraction and real-time polymerase chain reaction

DNA extraction from the clinical samples was carried out using High Pure Viral Nucleic Acid Kit according to the user manual (Roche Applied Science, Mannheim, Germany). For the quantitative detection of EBV DNA and $P$. gingivalis in the samples, real-time polymerase chain reaction (PCR) was used $[5,6]$. DNA extracted from the cell lines AKATA and P. gingivalis TDC60 were used as positive control [28, 29]. PCR was performed using the following primer sets: EBV forward, 5'-CCTGGTCATCCTTTGCCA-3'; EBV reverse, 5'-TGCTTCGTTATAGCCGTAGT-3'; P. gingivalis forward, 5'-AGGCAGCTTGCCATACTGCG-3'; P. gingivalis reverse, 5'-ACTGTTAGCAACTACCGATGT-3'; GAPDH forward, 5'-GCACCGTCAAGGCTGAGAAC-3'; and GAPDH reverse, 5'-ATGGTGGTGAAGACGCCAGT-3', using the SYBR Premix Ex Taq in a TP800 thermal cycler dice realtime system (Takara-bio, Tokyo, Japan). PCR products comprised $95 \mathrm{bp}$ for EBV, $404 \mathrm{bp}$ for $P$. gingivalis, and $142 \mathrm{bp}$ for GAPDH, respectively. The amplification reactions were performed in a final volume of $25 \mu \mathrm{l} 2 \times$ SYBR Premix Ex Taq $(12.5 \mu \mathrm{l}), 0.4 \mu \mathrm{M}$ forward and reverse primers $(0.2 \mu \mathrm{l})$, and 50 ng complementary DNA (cDNA) $(5 \mu \mathrm{l})$ and $10 \mathrm{ng}$ cDNA $(1 \mu \mathrm{l})$ for GAPDH. To reduce variability between replicates, PCR premixes, which contain all reagents except for cDNA, were prepared and aliquoted into 0.2-ml Hi-8-tubes (TakaRa, Tokyo, Japan). The thermal cycling conditions were $10 \mathrm{~s}$ at $95^{\circ} \mathrm{C}$ and 40 cycles of $5 \mathrm{~s}$ at $95^{\circ} \mathrm{C}$ and $30 \mathrm{~s}$ at $60^{\circ} \mathrm{C}$. PostPCR melting curves confirmed the specificity of single-target amplification, and the expressions of EBV DNA and $P$. gingivalis relative to GAPDH were determined. The dynamic range of the real-time PCR assays were determined through serial dilution of DNA extracts either AKATA cells or P. gingivalis TDC60 of the standards in the range of $10^{10} \sim 10^{1}$ copies per $\mathrm{ml}[28,29]$.

Statistical analysis

Fisher's exact probability test was used to determine whether individual pathogens were associated with chronic 
periodontitis. $P$ values $<0.05$ were considered statistically significant.

\section{Results}

Characteristics of patients and clinical data are summarized in Table 1 . The average PPD $(n=26)$ of the HC was $2.77 \pm$ $0.43 \mathrm{~mm}$. Among CP patients $(n=25)$, the two periodontal sites of PPD ( $\leq 3$ and $\geq 5 \mathrm{~mm}$ ) were $2.84 \pm 0.37$ and $6.28 \pm$ $1.28 \mathrm{~mm}$, respectively. BOP was detected $3.8 \%$ in $\mathrm{HC}$ and 4 or $72 \%$ in shallow $(\leq 3 \mathrm{~mm})$ or deep PPD $(\geq 5 \mathrm{~mm})$ sites from CP patients.

Table 2 describes clinical data and counts of EBV DNA and $P$. gingivalis in the CP patients. Two PCR-positive periodontal sites of PPD ( $\leq 3$ and $\geq 5 \mathrm{~mm}$ ) of CP patients for EBV DNA range from $4.37 \times 10^{4} \sim 9.13 \times 10^{6}$ copies $/ \mathrm{ml}(\leq 3 \mathrm{~mm})$ and $3.74 \times 10^{3} \sim 2.83 \times 10^{9}$ copies $/ \mathrm{ml}(\geq 5 \mathrm{~mm})$, and for P. gingivalis were $3.97 \times 10^{6} \sim 2.13 \times 10^{9}$ copies $/ \mathrm{ml}(\leq 3 \mathrm{~mm})$ and $2.73 \times 10^{5} \sim 6.65 \times 10^{9}$ copies $/ \mathrm{ml}$, respectively. Table 3 shows clinical data and counts of EBV DNA and $P$. gingivalis in the HC. PCR-positive sites of PPD ( $\leq 3 \mathrm{~mm}$ ) of HC for EBV DNA range from $1.27 \times 10^{4} \sim 2.66 \times 10^{8}$ copies $/ \mathrm{ml}$ and for $P$. gingivalis were $4.16 \times 10^{6} \sim 6.62 \times 10^{9}$ copies $/ \mathrm{ml}$, respectively.

The occurrence frequencies of EBV DNA and $P$. gingivalis in the $\mathrm{HC}$ and patients with $\mathrm{CP}$ are listed in Table 4. EBV DNA was detected in $13(50 \%)$ periodontal pockets of $\mathrm{HC}$ and in $10(40 \%)$ and $20(80 \%)$ of the shallow $(\leq 3 \mathrm{~mm})$ and deeper PPD sites $(\geq 5 \mathrm{~mm}$ ) of patients with CP, respectively. P. gingivalis was detected in $7(27 \%)$ periodontal pockets of $\mathrm{HC}$ and in $9(36 \%)$ and $20(80 \%)$ of the shallow $(\leq 3 \mathrm{~mm})$ and deeper PPD sites ( $\geq 5 \mathrm{~mm}$ ) of CP patients, respectively. EBV DNA and $P$. gingivalis were detected with higher frequencies in deeper PPD sites of CP patients than in PPD sites of HC. Additionally, EBV DNA and $P$. gingivalis were significantly more frequent in deeper PPD sites than in shallow PPD sites of $\mathrm{CP}$ patients. The occurrence frequency of EBV DNA (50 \%)

Table 1 Characteristics of subjects and clinical data in this study

\begin{tabular}{lll}
\hline & HC $(13$ healthy individuals $)$ & CP $(25 \mathrm{CP}$ patients $)$ \\
\hline Age & $52.9 \pm 18.0$ & $54.2 \pm 13.8$ \\
Males & $2(15 \%)$ & $8(32 \%)$ \\
Females & $11(85 \%)$ & $17(68 \%)$ \\
PPD & $2.77 \pm 0.43(n=26)$ & $2.84 \pm 0.37(\leq 3 \mathrm{~mm} ; n=25)$ \\
& & $6.28 \pm 1.28(\geq 5 \mathrm{~mm} ; n=25)$ \\
BOP & $1(3.8 \%)(n=26)$ & $1(4 \%)(\leq 3 \mathrm{~mm} ; n=25)$ \\
& & $18(72 \%)(\geq 5 \mathrm{~mm} ; n=25)$ \\
\hline
\end{tabular}

$H C$ healthy controls, $C P$ chronic periodontitis was higher than $P$. gingivalis ( $27 \%$ ) in PPD sites of HC. However, EBV DNA and $P$. gingivalis were detected at almost similar frequencies in shallow PPD sites (40 and $36 \%$ ) and in deeper PPD sites ( 80 and $80 \%$ ) of CP patients. Coexistence of EBV DNA and $P$. gingivalis was significantly higher in the deeper PPD sites of CP patients (68\%) than in the PPD sites of the HC (15\%) and shallow PPD sites of CP patients (12\%).

\section{Discussion}

Although bacteria play an essential role in the etiology of periodontal disease, it has become increasingly clear that herpes viruses, especially EBV, are involved in the etiology of several types of periodontal disease because bacterial activity alone does not adequately explain several clinical characteristics of periodontal disease [7, 15]. In fact, a purely bacterial cause of aggressive periodontitis does not explain why the disease tends to develop bilaterally symmetric and site-specific and why vertical bone resorption can advance at one tooth while barely affecting the periodontium of an adjacent tooth sharing the interproximal space [7, 30]. Junctional epithelial cells from the gingiva were infected with EBV, and the EBV infection was significantly increased with disease severity [31]. The results suggest that gingival epithelial cells may serve as an oral reservoir of latent EBV-infected cells. The results of this study reveal an association between EBV DNA and deep PPD sites and, likewise, $P$. gingivalis and deep PPD sites ( $\geq 5 \mathrm{~mm}$ ) of CP lesions. Furthermore, EBV DNA and $P$. gingivalis coexist in the deep PPD sites of CP patients at high frequency ( $68 \%$ ). These results correlated with previous studies that showed statistically significant levels of EBV DNA in CP patients compared with healthy individuals [15, 21]. Slots and his collaborators discovered more EBV DNA in the gingival crevicular fluid and saliva of periodontal patients, and the increase in EBV counts with increasing severity of periodontitis lends substantial support to a periodontopathic role of EBV [6, 20, 22-24]. The data showed that EBV DNA was detected at $\sim 300$-fold higher copy numbers in the PCRpositive deep PPD compared to shallow PPD sites. Moreover, $P$. gingivalis was detected at $\sim 3$-fold higher copy numbers in the PCR-positive deep PPD compared to shallow PPD sites, in spite of having high EBV DNA and $P$. gingivalis-negative shallow PPD sites among both patients with $\mathrm{CP}$ and $\mathrm{HC}$ (Tables 2 and 3). These results suggest that high copy numbers of EBV DNA and $P$. gingivalis may reflect the severity of inflammation. In the previous report, range of counts in PCRpositive sites of periodontitis patients and periodontally normal subjects for EBV DNA (positive $\%$; 60 and $13 \%$ ) were $2.1 \times 10^{3} \sim 8.3 \times 10^{8}$ and $2.4 \times 10^{3} \sim 3.2 \times 10^{4}$ copies $/ \mathrm{ml}$, and for P. gingivalis (positive $\%$; 87 and $13 \%$ ) were $5 \times 10^{3} \sim 1 \times 10^{10}$ and $2.1 \times 10^{4} \sim 3.1 \times 10^{6}$ copies $/ \mathrm{ml}[6]$. The results showed that copy numbers of EBV DNA and $P$. gingivalis in the 
Table 2 Clinical data and counts of EBV DNA and $P$. gingivalis in the chronic periodontitis patients

\begin{tabular}{|c|c|c|c|c|c|c|c|c|c|c|}
\hline $\begin{array}{l}\text { Subject } \\
\text { no. }\end{array}$ & Gender & Age & $\begin{array}{l}\text { PPD } \\
(\leqq 3, \mathrm{~mm})\end{array}$ & BOP & $\begin{array}{l}\text { EBV } \\
\text { (copies/ml) }\end{array}$ & $\begin{array}{l}\text { P. gingivalis } \\
\text { (copies/ml) }\end{array}$ & $\begin{array}{l}\text { PPD } \\
(\leqq 5, \mathrm{~mm})\end{array}$ & BOP & $\begin{array}{l}\text { EBV } \\
\text { (copies/ml) }\end{array}$ & $\begin{array}{l}P \text {. gingivalis } \\
\text { (copies } / \mathrm{ml} \text { ) }\end{array}$ \\
\hline 1 & Male & 56 & 3 & - & ND & ND & 8 & + & $4.69 \times 10^{4}$ & $7.65 \times 10^{5}$ \\
\hline 2 & Male & 57 & 3 & - & $1.09 \times 10^{6}$ & ND & 8 & + & $7.16 \times 10^{4}$ & $4.26 \times 10^{7}$ \\
\hline 3 & Female & 58 & 3 & - & ND & $2.13 \times 10^{9}$ & 6 & - & ND & $2.86 \times 10^{8}$ \\
\hline 4 & Female & 62 & 3 & - & $1.22 \times 10^{6}$ & ND & 7 & + & $8.85 \times 10^{5}$ & $2.46 \times 10^{6}$ \\
\hline 5 & Female & 52 & 2 & - & $4.37 \times 10^{4}$ & $3.97 \times 10^{6}$ & 7 & + & $2.72 \times 10^{5}$ & $2.22 \times 10^{6}$ \\
\hline 6 & Female & 40 & 3 & - & ND & $4.10 \times 10^{7}$ & 6 & + & ND & $1.29 \times 10^{7}$ \\
\hline 7 & Male & 59 & 3 & - & ND & $\mathrm{ND}$ & 6 & + & $1.23 \times 10^{7}$ & $2.79 \times 10^{7}$ \\
\hline 8 & Female & 29 & 3 & - & $9.13 \times 10^{6}$ & ND & 8 & + & $8.60 \times 10^{5}$ & $2.11 \times 10^{6}$ \\
\hline 9 & Female & 63 & 3 & - & $4.20 \times 10^{5}$ & $8.95 \times 10^{6}$ & 5 & - & $1.05 \times 10^{6}$ & $1.71 \times 10^{7}$ \\
\hline 10 & Female & 27 & 3 & - & $9.33 \times 10^{5}$ & ND & 5 & - & $3.70 \times 10^{7}$ & $\mathrm{ND}$ \\
\hline 11 & Female & 63 & 3 & - & ND & $7.75 \times 10^{7}$ & 8 & + & $3.06 \times 10^{4}$ & $2.21 \times 10^{7}$ \\
\hline 12 & Male & 82 & 3 & - & $4.85 \times 10^{6}$ & $1.32 \times 10^{8}$ & 6 & + & $2.83 \times 10^{9}$ & $6.65 \times 10^{9}$ \\
\hline 13 & Male & 58 & 3 & - & $2.89 \times 10^{6}$ & ND & 5 & - & $1.67 \times 10^{7}$ & $2.13 \times 10^{8}$ \\
\hline 14 & Female & 49 & 3 & - & ND & ND & 6 & + & $3.74 \times 10^{3}$ & $1.09 \times 10^{8}$ \\
\hline 15 & Female & 72 & 3 & - & ND & ND & 6 & + & $6.65 \times 10^{3}$ & $2.79 \times 10^{7}$ \\
\hline 16 & Female & 39 & 2 & - & ND & ND & 5 & + & ND & ND \\
\hline 17 & Male & 54 & 3 & - & ND & $7.81 \times 10^{6}$ & 6 & + & $8.79 \times 10^{3}$ & $3.73 \times 10^{6}$ \\
\hline 18 & Female & 42 & 3 & - & ND & $1.33 \times 10^{8}$ & 10 & + & $4.93 \times 10^{4}$ & $1.15 \times 10^{9}$ \\
\hline 19 & Female & 60 & 3 & - & ND & $\mathrm{ND}$ & 5 & - & $3.22 \times 10^{6}$ & ND \\
\hline 20 & Female & 33 & 3 & - & ND & $2.45 \times 10^{7}$ & 6 & + & $4.35 \times 10^{4}$ & $5.64 \times 10^{8}$ \\
\hline 21 & Male & 49 & 3 & - & $7.96 \times 10^{5}$ & ND & 5 & - & $1.96 \times 10^{5}$ & ND \\
\hline 22 & Female & 61 & 2 & - & ND & ND & 6 & + & $\mathrm{ND}$ & $3.56 \times 10^{6}$ \\
\hline 23 & Male & 79 & 2 & - & ND & ND & 6 & + & $1.72 \times 10^{4}$ & $1.64 \times 10^{8}$ \\
\hline 24 & Female & 59 & 3 & + & $1.41 \times 10^{5}$ & ND & 6 & + & $1.21 \times 10^{4}$ & $2.73 \times 10^{5}$ \\
\hline 25 & Female & 52 & 3 & - & ND & ND & 5 & - & $\mathrm{ND}$ & ND \\
\hline
\end{tabular}

$N D$ not detectable

Table 3 Clinical data and counts of EBV DNA and $P$. gingivalis in the healthy controls

\begin{tabular}{|c|c|c|c|c|c|c|c|c|c|c|}
\hline $\begin{array}{l}\text { Subject } \\
\text { no. }\end{array}$ & Gender & Age & $\begin{array}{l}\text { PPD } \\
(\leqq 3, \mathrm{~mm})\end{array}$ & BOP & $\begin{array}{l}\text { EBV } \\
\text { (copies/ml) }\end{array}$ & $\begin{array}{l}\text { P. gingivalis } \\
\text { (copies/ml) }\end{array}$ & $\begin{array}{l}\mathrm{PPD}, \\
(\leqq 3, \mathrm{~mm})\end{array}$ & BOP & $\begin{array}{l}\text { EBV, } \\
\text { (copies/ml) }\end{array}$ & $\begin{array}{l}\text { P. gingivalis } \\
\text { (copies } / \mathrm{ml} \text { ) }\end{array}$ \\
\hline 1 & Female & 64 & 3 & - & ND & ND & 3 & - & ND & ND \\
\hline 2 & Female & 72 & 3 & - & ND & ND & 3 & - & $1.30 \times 10^{7}$ & ND \\
\hline 3 & Female & 72 & 3 & - & ND & ND & 3 & - & ND & ND \\
\hline 4 & Female & 40 & 3 & - & $1.09 \times 10^{5}$ & ND & 3 & - & ND & ND \\
\hline 5 & Male & 28 & 2 & - & ND & ND & 3 & - & ND & ND \\
\hline 6 & Female & 26 & 2 & - & ND & ND & 3 & - & ND & $\mathrm{ND}$ \\
\hline 7 & Female & 64 & 3 & - & $8.15 \times 10^{7}$ & $1.41 \times 10^{9}$ & 3 & - & $2.58 \times 10^{7}$ & $8.34 \times 10^{7}$ \\
\hline 8 & Female & 64 & 3 & - & ND & $6.62 \times 10^{9}$ & 3 & - & $2.20 \times 10^{6}$ & ND \\
\hline 9 & Female & 46 & 3 & - & $2.66 \times 10^{8}$ & ND & 2 & - & $3.59 \times 10^{7}$ & ND \\
\hline 10 & Male & 73 & 3 & - & $2.33 \times 10^{5}$ & ND & 3 & - & $1.27 \times 10^{4}$ & $5.96 \times 10^{8}$ \\
\hline 11 & Female & 56 & 2 & - & $5.81 \times 10^{5}$ & ND & 2 & + & ND & $1.61 \times 10^{7}$ \\
\hline 12 & Female & 25 & 3 & - & $2.46 \times 10^{6}$ & ND & 2 & - & $2.55 \times 10^{6}$ & ND \\
\hline 13 & Female & 58 & 3 & - & $2.56 \times 10^{5}$ & $4.16 \times 10^{6}$ & 3 & - & ND & $9.17 \times 10^{6}$ \\
\hline
\end{tabular}


Table 4 Occurrence of EBV DNA and $P$. gingivalis in the subgingival samples from $\mathrm{HC}$ and $\mathrm{CP}$ patients

\begin{tabular}{|c|c|c|c|c|c|c|}
\hline \multirow[b]{2}{*}{ Infectious agents } & \multicolumn{3}{|c|}{ Detection frequency } & \multicolumn{3}{|c|}{ Significance ( $P$ value) } \\
\hline & $\mathrm{HC}(n=26)$ & $\begin{array}{l}\mathrm{CP}(\leq 3 \mathrm{~mm}) \\
(n=25)\end{array}$ & $\begin{array}{l}\mathrm{CP}(\geq 5 \mathrm{~mm}) \\
(n=25)\end{array}$ & $\begin{array}{l}\text { HC vs } \\
\mathrm{CP}(\leq 3 \mathrm{~mm})\end{array}$ & $\begin{array}{l}\text { HC vs } \\
\mathrm{CP}(\geq 5 \mathrm{~mm})\end{array}$ & $\begin{array}{l}\mathrm{CP}(\leq 3 \mathrm{~mm}) \mathrm{vs} \\
\mathrm{CP}(\geq 5 \mathrm{~mm})\end{array}$ \\
\hline EBV & $13(50 \%)$ & $10(40 \%)$ & $20(80 \%)$ & 0.33 & $0.025^{*}$ & $0.0043 * *$ \\
\hline P. gingivalis & $7(27 \%)$ & $9(36 \%)$ & $20(80 \%)$ & 0.35 & $0.00017 * *$ & $0.0018 * *$ \\
\hline $\mathrm{EBV}+P$. gingivalis & $4(15 \%)$ & $3(12 \%)$ & $17(68 \%)$ & 0.52 & $0.00015^{* *}$ & $0.00006^{* *}$ \\
\hline
\end{tabular}

$* P<0.05, * * P<0.01$, statistically significant

periodontal lesions were almost the same as in our study (Table 2); however, their copy numbers in the normal subjects were lower compared to our data (Table 3). EBV DNA was detected at higher rate in the PPD sites of HC (50\%) than in the shallow PPD sites of CP (40\%). On the other hand, $P$. gingivalis was detected at higher rate in the shallow PPD sites of CP (36\%) than in the PPD sites of HC $(27 \%)$ (Table 4). These results might be caused by higher latent infection rate of healthy Japanese by EBV.

We have previously reported B cell marker CD19 immunostaining showed that a large number of $\mathrm{B}$ cells had infiltrated into the gingival connective tissues of patients with periodontitis [15]. And the results of in situ hybridization using EBV-encoded small RNA (EBRE) showed a large number of $\mathrm{B}$ cells in the same location that were EBER-positive [15]. Results suggest that EBV copy numbers in the subgingival plaque samples may relate to the severity of inflammation and the numbers of inflammatory cell infiltration in the gingiva.

The mechanisms of EBV reactivation and activated EBV progressing to periodontal disease have not been determined. Latent EBV in B cells can be reactivated to switch to lytic replication. EBV reactivation can be induced in vitro by a variety of stimuli, including 12-O-tetradecanoylphorbol-13acetate and anti-immunoglobulin, but a causal relationship between a coinfection with EBV and periodontopathic bacteria and the disruption of viral latency is not well understood. We have previously reported that the culture supernatant from $P$. gingivalis, which contains high concentrations of butyric acid, inhibits histone deacetylase and thus increases histone acetylation and transcriptional activity of the EBV BZLF1 gene, which encodes the master regulator protein (ZEBRA) for the transition from latency to the lytic replication cycle [25]. Given that regulation of the switch from latency to reactivation is an initial key step in EBV infection, these observations suggest that butyric acid-producing periodontopathic bacteria, such as $P$. gingivalis, have the potential to trigger EBV reactivation in the oral cavity of infected individuals [25]. EBV-infected inflamed periodontal sites tend to harbor elevated levels of periodontopathic bacteria $[15,21,23,32]$. Furthermore, bacterial and viral coinfections were also reported more frequently in deep periodontal pockets $[14,15,21,23]$. EBV-1, EBV-2, and $P$. gingivalis were detected in $72.5,10$, and $95 \%$ of sites with probing pocket depths $\geq 6 \mathrm{~mm}$, respectively [21]. We also reported that $\mathrm{EBV}$ and $P$. gingivalis were detected in 66 and $65 \%$ of sites with probing pocket depths $\geq 5 \mathrm{~mm}$, and EBV DNA and $P$. gingivalis coinfection was found in $42 \%$ of sites with probing pocket depths $\geq 5 \mathrm{~mm}$ [15]. These observations suggest that a "negative chain reaction" by EBV and periodontopathic bacteria may contribute to the etiopathogenesis of periodontitis [33].

In summary, we performed quantitative analysis of EBV DNA and $P$. gingivalis in Japanese chronic periodontitis patients which to our knowledge is the first such attempt. EBV DNA and $P$. gingivalis were detected in higher copy numbers in PCR-positive deep PPD and showed a higher incidence of the coexistence as compared to shallow PPD sites. Taking into account that periodontopathic anaerobic bacteria may increase the virulence of EBV via reactivation of EBV through butyric acid, their suppression or eradication may become an effective treatment to block EBV reactivation for early treatment or prevention of chronic periodontitis.

Acknowledgments This work was supported in part by a Grant-in-Aid for Scientific Research (C; No. 25463229), Nihon University Multidisciplinary Research Grant for 2014, and a grant of Strategic Research Base Development Program for Private Universities from the Ministry of Education, Culture, Sports, Science, and Technology, Japan (MEXT), 2010-2014 (S1001024).

Conflict of interest The authors declare that they have no conflict of interest.

Open Access This article is distributed under the terms of the Creative Commons Attribution License which permits any use, distribution, and reproduction in any medium, provided the original author(s) and the source are credited.

\section{References}

1. Kinane DF, Attstrom R (2005) Advances in the pathogenesis of periodontitis. Consensus report. J Clin Periodontol 32(6):130-131

2. Haffajee AD, Socransky SS (2005) Microbiology of periodontal diseases: introduction. Periodontol 38:9-12 
3. Ximenez-Fyvie LA, Haffajee AD, Socransky SS (2000) Comparison of the microbiota of supra- and subgingival plaque in health and periodontitis. J Clin Periodontol 27:648-657

4. Listgarten MA, Wong MY, Lai CH (1995) Detection of Actinobacillus actinomycetemcomitans, Porphyromonas gingivalis, and Bacteroides forsythus in an A. actinomycetemcomitans-positive patient population. J Periodontol 66:158-164

5. Sakamoto M, Takeuchi Y, Umeda M, Ishikawa I, Benno Y (2001) Rapid detection and quantification of five periodontopathic bacteria by real-time PCR. Microbiol Immunol 45:39-44

6. Saygun I, Kubar A, Sahin S, Sener K, Slots J (2008) Quantitative analysis of association between herpesviruses and bacterial pathogens in periodontitis. J Periodont Res 43:352-359

7. Slots J (2010) Human viruses in periodontitis. Periodontol 2000 53: 89-110

8. Tao Q, Young LS, Woodman CB, Murray PG (2006) Epstein-Barr virus (EBV) and its associated human cancers - genetics, epigenetics, pathobiology and novel therapeutics. Front Biosci 11:2672-2713

9. Thorley-Lawson DA, Gross A (2004) Persistence of the Epstein-Barr virus and the origins of associated lymphomas. N Engl J Med 350: $1328-1337$

10. Lin JC, Lin SC, De BK, Chan WP, Evatt BL (1993) Precision of genotyping of Epstein-Barr virus by polymerase chain reaction using three gene loci (EBNA-2, EBNA-3C, and EBER): predominance of type A virus associated with Hodgkin's disease. Blood 81:3372-3381

11. Maeda E, Akahane M, Kiryu S, Kato N, Yoshikawa T, Hayashi N, Aoki S, Minami M, Uozaki H, Fukayama M, Ohtomo K (2009) Spectrum of Epstein-Barr virus-related diseases: a pictorial review. Jpn J Radiol 27:4-19

12. Toussirot E, Roudier J (2008) Epstein-Barr virus in autoimmune diseases. Best Pract Res Clin Rheumatol 22:883-896

13. Timms JM, Bell A, Flavell JR, Murray PG, Rickinson AB, TraverseGlehen A, Berger F, Delecluse HJ (2003) Target cells of EpsteinBarr-virus (EBV)-positive post-transplant lymphoproliferative disease: similarities to EBV -positive Hodgkin's lymphoma. Lancet 361:217-223

14. Slots J, Saygun I, Sabeti M, Kubar A (2006) Epstein-Barr virus in oral diseases. J Periodontal Res 41:235-244

15. Kato A, Imai K, Ochiai K, Ogata Y (2013) Higher prevalence of Epstein-Barr virus DNA in deeper periodontal pockets of chronic periodontitis in Japanese patients. PLoS One 8(8):e71990

16. Sahin S, Saygun I, Kubar A, Slots J (2009) Periodontitis lesions are the main source of salivary cytomegalovirus. Oral Microbiol Immunol 24:340-342

17. Idesawa M, Sugano N, Ikeda K, Oshikawa M, Takane M, Seki K, Ito K (2004) Detection of Epstein-Barr virus in saliva by real-time PCR. Oral Microbiol Immunol 19:230-232

18. Contreras A, Nowzari H, Slots J (2000) Herpesviruses in periodontal pocket and gingival tissue specimens. Oral Microbiol Immunol 15: $15-18$
19. Klemenc P, Skaleric U, Artnik B, Nograsek P, Marin J (2005) Prevalence of some herpesviruses in gingival crevicular fluid. $\mathrm{J}$ Clin Virol 34:147-152

20. Kubar A, Saygun I, Ozdemir A, Yapar M, Slots J (2005) Real-time polymerase chain reaction quantification of human cytomegalovirus and Epstein-Barr virus in periodontal pockets and the adjacent gingiva of periodontitis lesions. J Periodontal Res 40:97-104

21. Chalabi M, Rezaie F, Moghim S, Mogharehabed A, Rezaei M, Mehraban B (2010) Periodontopathic bacteria and herpesviruses in chronic periodontitis. Mol Oral Micobiol 25:236-240

22. Ting M, Contreras A, Slots J (2000) Herpesvirus in localized juvenile periodontitis. J Periodontal Res 35:17-25

23. Saygun I, Kubar A, Ozdemir A, Yapar M, Slots J (2004) Herpesviralbacterial interrelationships in aggressive periodontitis. J Periodontal Res 39:207-212

24. Saygun I, Kubar A, Ozdemir A, Slots J (2005) Periodontitis lesions are a source of salivary cytomegalovirus and Epstein-Barr virus. J Periodontal Res 40:187-191

25. Imai $\mathrm{K}$, Inoue $\mathrm{H}$, Tamura $\mathrm{M}$, Cueno $\mathrm{ME}$, Inoue $\mathrm{H}$, Takeichi $\mathrm{O}$, Kusama K, Saito I, Ochiai K (2012) The periodontal pathogen Porphyromonas gingivalis induces the Epstein-Barr virus lytic switch transactivator ZEBRA by histone modification. Biochimie 94:839_ 846

26. Slots J, Slots H (2011) Bacterial and viral pathogens in saliva: disease relationship and infectious risk. Periodontol 2000 55:48-69

27. Ikuta K, Satoh Y, Hoshikawa Y, Sairenji T (2000) Detection of Epstein-Barr virus in salivas and throat washings in healthy adults and children. Microbes Infect 2:115-120

28. Takada K, Horinouchi K, Ono Y, Aya T, Osato T, Takahashi M, Hayasaka S (1991) An Epstein-Barr virus-producer line Akata: establishment of the cell line and analysis of viral DNA. Virus Genes 5: $147-156$

29. Watanabe T, Maruyama F, Nozawa T, Aoki A, Okano S, Shibata Y, Oshima K, Kurokawa K, Hattori M, Nakagawa I, Abiko Y (2011) Complete genome sequence of the bacterium Porphyromonas gingivalis TDC60, which causes periodontal disease. J Bacteriol 193:4259-4260

30. Slots J (2010) Herpesviral-bacterial interactions in periodontal diseases. Periodontol 2000 52:117-140

31. Vincent-Bugnas S, Vitale S, Mouline CC, Khaali W, Charbit Y, Mahler P, Prêcheur I, Hofman P, Maryanski JL, Doglio A (2013) EBV infection is common in gingival epithelial cells of the periodontium and worsens during chronic periodontitis. PLoS One 8(12): e80336

32. Contreras A, Slots J (2000) Herpesviruses in human periodontal disease. J Periodont Res 35:3-16

33. Imai K, Ogata Y, Ochiai K (2012) Microbial interaction of periodontopathic bacteria and Epstein-Barr virus and their implication of periodontal diseases. J Oral Biosci 54:164-168 